\title{
A CONSTRUÇÃO DE SI E DO OUTRO NA AUTOBIOGRAFIA DE UMA PROFESSORA MISSIONÁRIA
}

LOYDE ANNE CARREIRO SILVA VERAS

Pontifícia Universidade Católica do Paraná

\section{EVELYN DE ALMEIDA ORLANDO}

Pontifícia Universidade Católica do Paraná

Este artigo parte de uma análise do livro 8:28, a autobiografia de Eva Yarwood Mills, publicada em 1976, em Lancaster, Estados Unidos. Eva Mills veio da Inglaterra para o Brasil, como uma missionária protestante, no período de 1928 a 1959, vindo a aposentar-se nos Estados Unidos, onde e quando publica seu livro. A partir da materialidade do $8: 28$, procuramos identificar os sentidos acionados pela autora nas representações tanto de si, quanto do grupo religioso ao qual ela pertencia. Conjuntamente, exploramos os elementos do pacto-autobiográfico e discutimos as estratégias com que estes foram acionados, a partir da relação entre editor, autora-narradora-personagem e público leitor. Identificamos um livro rico em sentidos e caminhos de análise possíveis, capaz de suscitar questões relevantes como as estratégias usadas na representação de uma vida, os usos da autobiografia na construção identitária de um sujeito e do grupo ao qual ele pertence e os papéis que a educação assume na vida desta personagem, a partir de seu lugar de pertença. Apesar de Eva Mills ser uma professora e construir-se por meio da educação, é na relação com o grupo religioso da sua velhice, que ela se reelabora enquanto missionária e se legitima como educadora que esteve a serviço de uma missão protestante europeia-americana (auto)definida como civilizadora.

Palavras-chave: Educação. Autobiografia. Protestantismo.

\section{ABSTRACT}

THE CONSTRUCTION OF ONESELF AND OTHERS IN THE

\section{AUTOBIOGRAPHY OF A MISSIONARY TEACHER}

This article is an analysis of the book 8:28, the autobiography of Eva Yarwood Mills published in 1976, in Lancaster, United States. Eva Mills 
lived and worked in Brazil as a Protestant missionary from 1928 to 1959, working in the area of education in the states of Maranhão, Pará, Pernambuco and Ceará, and she retired to the United States, where and when she published her book. From the book's materiality, identifying the author's senses in the representations of both himself and the religious group to which he belongs. We explore the elements of the autobiographical pact and discuss the strategies with which they are triggered from the relationship between publisher, author-character and readership. We identified in this research a book rich in analyses paths, capable of raising important questions such as the strategies used in the representation of a life, the uses of autobiography in the identity construction of a subject and the group to which he belongs and the roles which education assumes in the life of this character from his place of belonging. Although Eva Mills is a teacher and building herself through education, it is in the relationship with the religious group of her old age that she reelaborates as a missionary and legitimizes herself as an educator who has been in the service of a mission European-American Protestant (self) defined as a civilizer.

Keywords: Education. Autobiography. Protestantism.

\section{RESUMEN}

\section{LA CONSTRUCCIÓN DE SI Y DEL OTRO EN LA AUTOBIOGRAFÍA DE UNA PROFESORA MISIONERA}

Este artículo es un análisis del libro 8:28, la autobiografia de Eva Yarwood Mills publicada en 1976, en Lancaster, Estados Unidos. Eva Mills vivió y trabajó en Brasil como misionera protestante desde 1928 hasta 1959, trabajando en el área de educación en los estados de Maranhão, Pará, Pernambuco y Ceará, y se retiró a los Estados Unidos, donde y cuando publicó su libro. De la materialidad del libro, identificar los sentidos del autor en las representaciones de él mismo y del grupo religioso al que pertenece. Exploramos los elementos del pacto autobiográfico y discutimos las estrategias con las cuales se desencadenan a partir de la relación entre editor, autor-personaje y lectores. Identificamos en esta investigación un libro rico en posibles direcciones y análisis, capaz de plantear preguntas importantes como las estrategias utilizadas en la representación de una vida, los usos de la autobiografía en la construcción de identidad de un sujeto y el grupo al que pertenece y los roles que la educación asume en la vida de este personaje desde su lugar de pertenencia. Aunque Eva Mills es maestra y se está forjando a través de la educación, es en la relación con el grupo religioso de su vejez que reelabora como 
misionera y se legitima como educadora que ha estado al servicio de una misión protestante europeo-estadounidense (auto)definida como civilizadora.

Palabras clave: Educación. Autobiografia. Protestantismo.

\section{Introdução}

Aos 25 anos de idade, no dia 27 de setembro de 1928, Eva Yarwood aportava em terras brasileiras. Viera sozinha de navio da Inglaterra para se encontrar com o noivo, David Mills, que a esperava no porto de São Luís. Este foi, também, o dia de seu casamento. 0 plano do casal era juntar-se a Perrin Smith, um missionário canadense que trabalhava no interior do $\mathrm{Ma}$ ranhão desde idos de 1905. Nem o missionário, nem o recém casal possuíam alguma agência ou instituição missionária por trás de tais empreendimentos e vieram dispostos a desbravar o "interior primitivo do Norte do Brasil", pela causa missionária. (MILLS, 1976, Apresentação)

Esta é a narrativa encontrada na autobiografia de Eva Yarwood Mills (1903-1987), ou apenas Eva Mills, como nos remeteremos a ela, por ser o nome com que assinou por toda uma vida, desde aquele " 27 de setembro". Eva Mills assumiu a educação como seu campo privilegiado de atuação e, após trinta anos de estada neste país, há registros de iniciativas educacionais suas nos estados do Maranhão, Pará, Pernambuco e Ceará, especialmente com a abertura de escolas-internatos protestantes nesta região do país.

Eva Mills aposentou-se na década de 1970, recolhendo-se no Calvary Fellowship Homes, um lar para idosos nos Estados Unidos, não só por sua idade avançada, mas especialmente por sua saúde, acometida por uma leucemia aguda. Foi neste momento que ela veio a escrever e publicar três livros autobiográficos sobre seu tempo como uma professora missionária no interior do Brasil (MILLS, 1976; 1982[?]; 1985[?]).
Este artigo é uma parte da análise do primeiro livro publicado por Eva Mills, no ano de 1976, intitulado 8:28. É uma "narrativa retrospectiva em prosa" em que a autora-narradora-personagem "faz de sua própria existência, quando focaliza sua história individual" (LEJEUNE, 2008, p. 16). É neste livro onde Eva Mills propõe-se a narrar-se de forma veemente, escrevendo de si e construindo os sentidos de uma ação que justificou sua vida como uma professora missionária entre "nativos" brasileiros. ${ }^{2}$

Na historiografia da Educação no Brasil, pesquisas como as de Mignot (2002), Mignot e Cunha (2003), Souza e Passeggi (2011) e Silva (2014), entre outras, evidenciam um olhar mais atento às (auto)biografias como pistas importantes sobre os muitos caminhos da história da formação e da profissão docente que, apesar de terem suas particularidades próprias, estão intrinsecamente ligadas.

Faz parte desta análise a "compreensão dos sentidos", engendrados e refratados por

1 Esta é uma autobiografia no sentido "clássico" do termo, conforme Philippe Lejeune (2008). Contudo, segundo o próprio autor, um conceito restritivo àquilo que pode entrar no rol autobiográfico, excluindo outras formas de autobiografias como diários, relatos orais, autorretratos etc. Nos demais livros de Eva Mills, o estilo de narrativa e a evidência de si se alteram, ganhando outras proposições.

2 Este artigo é um recorte de pesquisa de mestrado onde a autora procurou evidenciar a vida e as obras de Eva Yarwood Mills, buscando compreender, a partir da materialidade e das representações postuladas nestes livros, a personagem e o campo onde a autora e seus livros se inserem. Os primeiros caminhos percorridos nesta análise foram apresentados no III Congresso Nacional de Educação - EDUCERE, em agosto de 2017, em Curitiba, Paraná, sendo esta uma edição não só revista em suas fontes, quanto ampliada em suas perspectivas de análise. 
um "sentido de trajetória", por uma “ilusão biográfica" construída nesta obra, a partir dos conceitos de Bourdieu (1996). Esta “ilusão biográfica" diz sobre uma realidade construída, tão real em sentidos quanto a realidade que se pretende alcançar, e faz referência à trajetória construída, ao sentido de linearidade, de lógica atribuída a uma vida. Em uma autobiografia, não é a vida que produz o texto, mas "é o texto que produz a vida" (LEJEUNE, 2008, p. 75).

Em busca de compreender a construção identitária iniciada neste primeiro livro, há um caminho a percorrer entre "a mão do autor e a mente do editor" (CHARTIER, 2014), ${ }^{3}$ entendendo que a "imagem no frontispício, ou na página do título, na orla do texto sugere uma leitura, constrói um significado" (CHARTIER, 1990, p. 133) capaz de erigir uma dada identidade desde a materialidade do livro. ${ }^{4}$

\section{O lugar da escrita}

8:28. O inusitado título desta obra, bem como a composição da capa do livro, foram ambos construídos de forma não só a provocar

3 "A mão do autor e a mente do editor" é o título de um livro de Roger Chartier, publicado no Brasil em 2014, e que denota a tônica de sua pesquisa em torno dos livros impressos. Para ele, há uma complexidade no processo de publicação de um livro que envolve desde a mão do autor (o processo de escrita) à mente do editor (o processo e o campo de publicação do impresso) e, por conseguinte, o público leitor (recepção) (CHARTIER, 2014). Este processo precisa ser considerado de forma dialógica entre o conteúdo do texto e a materialidade do livro, sendo esta a proposta metodológica deste trabalho.

4 "Um texto está sempre inscrito em uma materialidade: a do objeto escrito que o porta, a da voz que o lê ou o recita, a da representação que o dá a ouvir. Cada uma dessas formas é organizada de acordo com estruturas próprias que desempenham um papel essencial no processo de produção do sentido. Para ficar no escrito impresso, o formato do livro, as disposições da paginação, os modos de recorte do texto, as convenções tipográficas são investidas de uma "função expressiva" e sustentam a construção da significação. Organizados por uma intenção, a do autor ou do editor, esses dispositivos formais visam a forçar a recepção, a controlar a interpretação, a qualificar o texto. Estruturando o inconsciente da leitura (ou da escuta), eles são os suportes do trabalho da interpretação". (CHARTIER, 2002, p. 244) a curiosidade editorial, chamando a atenção para o que possa significar este número, quanto vindo a dialogar com a identificação da autora-personagem desta obra e de um determinado público leitor.

Figura 1 - Imagem de capa do livro 8:28

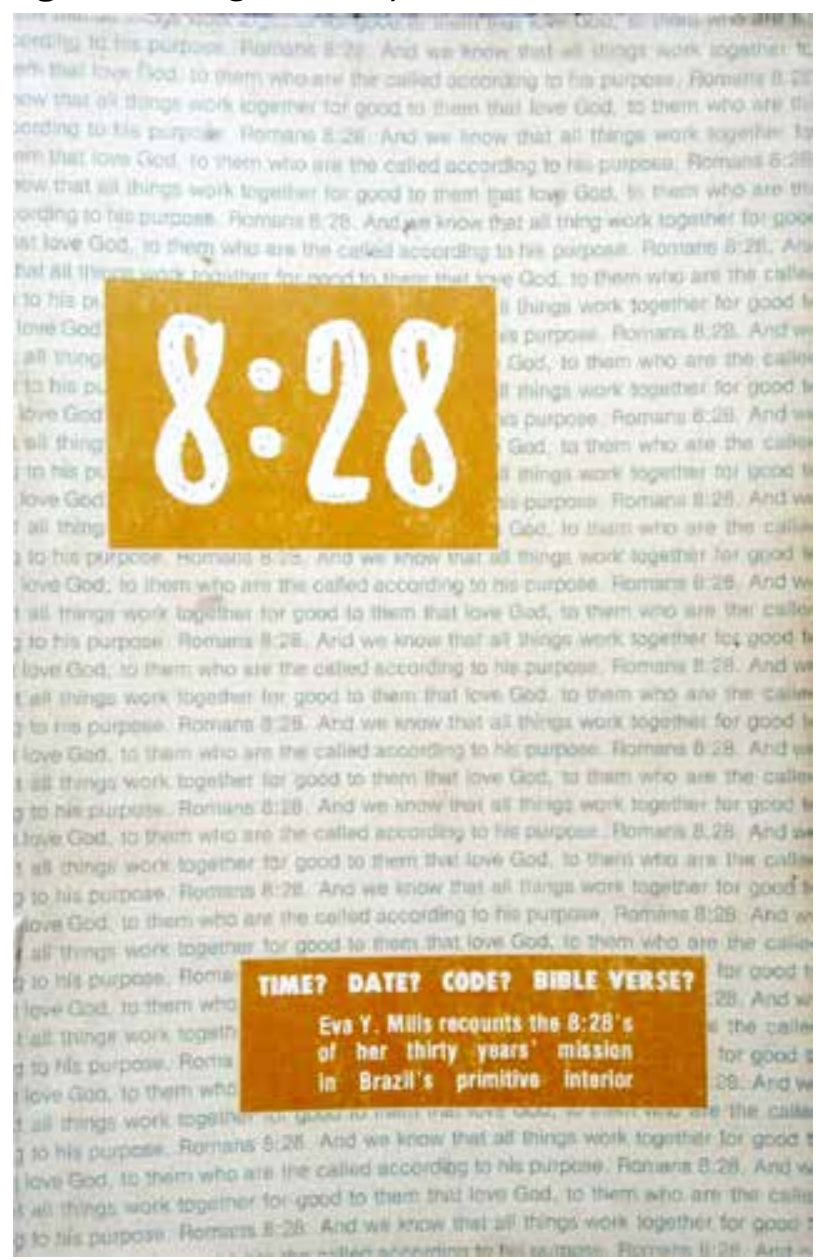

Fonte: Mills, 1976.

Um dos significados atribuídos ao título está na parte subscrita do quadro em marca d'água: uma imagem que lembra uma lauda de livro. Trata-se de um pequeno fragmento de texto bíblico repetido inúmeras vezes - "Romanos 8:28 - E nós sabemos que todas as coisas trabalham juntas para o bem daqueles que amam a Deus, para aqueles que são chamados de acordo com o seu propósito" (tradução livre). Na Apresentação do livro, Eva Mills justifica esta referência:

No, it isn't a Senate Joint Resolution, No.828, nor the beginning of my Social Security number. It isn't my telephone area code, nor even my 
number on the church roll. It is the declaration of Paul, the apostle of Jesus Christ, to the Romans, chapter 8 and verse 28 , a declaration that has become more and more precious to me, because I have proved it to be true and absolutely guaranteed to all those who love the same Lord Jesus Christ and are walking with Him in day by day communion. He declares: 'For we know that all things work together for good to them that love God, to them who are the called according to His purpose'. (MILLS, 1976)

A Bíblia é elemento fundante nesta escrita de si, selecionada a partir do grupo de pertencimento da autora. É por meio das lentes bíblicas, ou melhor, através das lentes do grupo protestante, que tudo parece ganhar cor. Eva Mills não está falando só, de si para si. Ela fala de um lugar, para outros e também de outros. Fez sentido para ela e para seu grupo pensar que "todas as coisas" - ou seja, tudo o que foi vivenciado por ela - foram capazes de trabalhar juntas e cooperar entre si para um determinado fim, como expresso em Romanos 8:28. Segundo esta perspectiva, nada estaria fora de eixo e as peças de sua vida se encaixariam como em um quebra-cabeça, coerente em suas unidades de encaixe, capazes de formar um todo com sentido: "Brazil was to be the country of my joys and sorrows, where I would prove, over and over again through the years, the grand overwhelming truth of Romans, chapter eight, and verse twenty-eight" (MILLS, 1976). ${ }^{6}$

5 [Não, esta não é uma resolução do Senado, n. 828, nem o início do meu número de segurança social. Não é o meu código de área de telefone, nem mesmo meu número no rol da igreja. É a declaração de Paulo, o apóstolo de Jesus Cristo, aos Romanos, capítulo 8 e verso 28 , uma declaração que se tornou cada vez mais preciosa para mim, porque eu tenho provado também ser verdadeira e absolutamente garantida também a todos os que amam o mesmo Senhor Jesus Cristo e estão caminhando em comunhão com Ele no dia a dia. Ele diz: "Porque sabemos que todas as coisas cooperam para o bem daqueles que amam a Deus, para aqueles que são chamados de acordo com o Seu propósito. Tradução nossa.]

6 [O Brasil passaria a ser o país de minhas alegrias e tristezas, onde eu iria provar, por inúmeras vezes através dos anos, a grande e esmagadora verdade de Romanos, capítulo oito, verso vinte e oito. Tradução nossa.]
Eva Mills constrói-se como parte de seu contexto, onde alegrias e tristezas advêm como expressões da "Providência divina", ao que ela recorre para colar os pedaços de uma vida vivida em partes, pelo menos se depender dos acionamentos da memória, que são fragmentados e desconexos, e traçar uma trajetória de vida com sentido, capaz de ser materializada em um livro. 0 texto bíblico foi capaz de the trazer uma razão de ser, um sentido de vida - o fim destas coisas que cooperam entre si é "o bem dos que amam a Deus", daqueles que são chamados segundo o "Seu propósito". Eva Mills não é apresentada como mais uma na multidão, ela se representa e é representada para e pelo grupo como um modelo a ser seguido, "chamada por Deus" para uma missão, "vocacionada" segundo o plano divino.

Esta ideia de Providência divina postulada por Eva Mills, a partir do texto de Romanos 8:28, assemelha-se à identificada por Max Weber, entre os calvinistas puritanos do século XVII, como uma missão para todos e, mais que um destino sobre o qual o indivíduo deva se resignar, um chamado à ação e ao trabalho: “A todos, sem distinção, a Providência divina pôs à disposição uma vocação (calling) que cada qual deverá reconhecer e na qual deverá trabalhar, e essa vocação [é] [...] uma ordem dada por Deus ao indivíduo a fim de que seja operante por sua glória" (WEBER, 2004, p. 145).

A presença de um texto da Bíblia na capa do livro também se constitui um indício da definição ou priorização de um público leitor específico. A Bíblia é fundamento importante no campo religioso protestante e sua utilização na capa, ou mesmo na justificação de uma escrita autobiográfica, diz sobre uma mulher que se pretende parte deste grupo e é legitimada por ele.

Para Roger Chartier, as representações do mundo social "são sempre determinadas pelos interesses de grupo que as forjam. Daí, para 
cada caso, o necessário relacionamento dos discursos proferidos com a posição de quem os utiliza" (1990, p. 17). Desta forma, faz-se necessário pensar na publicação do 8:28 como parte dos interesses de um grupo e não somente a partir do empreendimento individual de um sujeito. Um livro é escrito, pensado e publicado, para atender a objetivos tanto subjetivos quanto coletivos, porquanto é necessário que haja um público leitor interessado ou pretendido para aquela obra.

Na contracapa, há uma preocupação evidente com a definição dos propósitos deste livro e com qual grupo religioso em especial se pretende dialogar, pondo no mesmo círculo a autora, o leitor e o editor:

This world is sick: insecurity prevails, people deceive, drugs and lust allure and captivate, marriages collapse, fear and frightening experiences threaten to overwhelm, and despondency leads to despair. The purpose of this book is to encourage fellow believers-traveling along life's jungle trail-by a testimony of personal experience. God, who calls His children to give out His amazing message to this sick word, is utterly faithful: He will do as He has said. 'To those who love God, who are called according to His plan, everything that happens fits into a pattern for good' is J. B. Phillips translation of Romans 8:28. $\mathrm{He}$ is able to keep His children from falling and to present them without fault before the presence of His glory with exceeding joy (see Jude 24). I am happy to recommend this account of God's faithfulness to one of his missionary servants. It makes inspiring challenging to God's children everywhere. - James W. Reapsome, Editor, Evangelical Missions Quarterly. (MILLS, 1976, contracapa) ${ }^{7}$

7 [Este mundo está doente: a insegurança prevalece, pessoas enganam, drogas e luxúria fascinam e cativam, casamentos desmoronam, medos e experiências assustadoras ameaçam dominar e o desânimo leva ao desespero. O propósito deste livro é encorajar os crentes companheiros de viagem ao longo da trilha da selva da vida, através de um testemunho de experiência pessoal. Deus, que chama Seus filhos para levarem Sua maravilhosa mensagem a este mundo doente, é completamente fiel: Ele irá fazer como disse. "Para aqueles que amam a Deus, que são chamados de acordo com
O texto inicia falando de um mundo doente, das mazelas que se contrapõem à moral cristã: insegurança da vida, drogas, luxúria, pessoas que enganam, casamentos que desmoronam..., para então trazer o contraponto do livro que se pretende em um caminho oposto: encorajar "crentes companheiros", "filhos de Deus", a seguir pela "trilha da selva da vida" por um mundo melhor. A tônica do texto é quase uma conclamação, a novos missionários, a seguirem o modelo ideal da autora-personagem, sendo chancelado pelo editor do livro - que faz ele mesmo a honra de referendar o livro, e não por acaso. James W. Reapsome, o editor, é um nome de referência no campo em questão e não sem propósito ele ainda assina seu lugar de pertença institucional à Evangelical Missions Quarterly (EMQ).

A EMQ é uma revista missiológica publicada por Billy Graham Center, no Wheaton College, e se pretende academicamente voltada para professores e alunos universitários, com ênfase em missões evangélicas mundiais, ao mesmo tempo que visa atender ao público de missionários em campo nos diversos continentes, apresentando-se como o primeiro periódico para a comunidade missionária norte -americana. James Reapsome assina a edição destas revistas, que são trimestrais, desde o primeiro número, em 1964, até o ano de 1997, sendo não só editor, quanto autor de muitos artigos e livros, demonstrando ser alguém de relevância no cenário missiológico protestante norte-americano deste período. ${ }^{8}$

Seu plano, tudo o que acontece se encaixa dentro de um padrão para o bem", como diz a tradução de J. B. Phillips de Romanos 8:28. Ele é capaz de guardar Seus filhos da queda e apresentá-los sem culpa na presença de Sua glória com demasiada alegria (ver Judas 24). Eu me alegro em recomendar este relato da fidelidade de Deus para com uma de suas servas missionárias. Isto traz desafios inspiradores para todos os filhos de Deus. - James W. Reapsome, Editor, Evangelical Missions Quarterly. Tradução nossa.]

8 Conforme os sites das instituições - Evangelical Missions Quarterly. Disponivel em: <https://www.emqonline.com/about-us/mission>. Acesso em: 19 ago. 
Reapsome apresenta a autora-personagem como uma heroína, um testemunho de experiência pessoal: Eva Mills é um padrão a ser seguido no meio protestante. Neste sentido, compreendemos a identidade da biografada sendo construída de forma intimamente ligada à recepção do livro, àquilo que se quer despertar no leitor, ao mesmo tempo que relacionada à proposição identitária de um campo específico, quando a apresenta como padrão para este grupo. Em um de seus livros, Reapsome descreveu seu encontro com Eva Mills em um lar para idosos, o mesmo onde vivia sua mãe:

The first time I met her I recognized pure gold [...]. Regardless of her incurable illness, her eyes sparkled and her smile charmed me. I could not say No when she asked me to edit her book, which told the story of her life in Brazil. She called it '8:28. (REAPSOME, 2013, p. 58)

Pensando a partir de Certeau (2011) na construção memorialística de um santo, encontramos a representação de uma mulher que passou pelo seu processo de martírio: Eva Mills "trilhou a selva da vida" (nas palavras de Reapsome, na contracapa), durante "trinta anos de missão" (na capa); e não foi em qualquer lugar, mas no "interior primitivo do Brasil" (também na capa do livro). Mais adiante, na dedicatória do livro, a autora traz novamente a expressão "na trilha da selva da vida", como um caminho percorrido por ela. São referências ao suplício, às dificuldades enfrentadas entre os "silvícolas", retomadas e reforçadas de diferentes formas no corpo do texto. Nesta mesma dedicatória, há uma referência à “Ter-

2016; e - Wheaton College. Disponivel em: <http:// www.wheaton.edu/BGCE / Evangelism-Resources/ EMQ>. Acesso em: 19 ago. 2016; bem como o vídeo comemorativo dos 50 anos de publicação da revista. Disponível em: <https://vimeo.com/105870673>. Acesso em: 20 ago. 2016.

9 [A primeira vez que eu a encontrei reconheci ouro puro [...]. Independentemente da sua doença incurável, seus olhos brilhantes e seu sorriso me encantaram. Eu não pude dizer não quando ela me pediu para editar seu livro, que contava a história de sua vida no Brasil. Ela o chamou de '8:28'.] ra de Beulá",10 uma alusão ao céu agora ansiado por ela - "onde mansões estão preparadas para mim" - em contraste às selvas por onde ela passou.

Elementos da autobiografia de Eva Mills podem ser relacionados à estrutura do "discurso hagiográfico", percebida por Certeau (2011): a vida de martírio na idade adulta; a evocação de sua infância, articuladora de uma "vocação/ eleição" desde os primórdios; o relato dramático entre os tempos solitários de crise e centramento, e as "virtudes" de ordem pública.

A combinação dos atos, dos lugares e dos temas indica uma estrutura própria que se refere não essencialmente 'àquilo que se passou', como faz a história, mas 'àquilo que é exemplar'. As res gestae não constituem senão um léxico. Cada vida de santo deve ser antes considerada como um sistema que organiza uma manifestação graças à combinação topológica de 'virtudes' e de 'milagres'. (CERTEAU, 2011, p. 290, grifos do autor)

Estas virtudes identificadoras de um modus protestante não dizem respeito necessariamente aos milagres, normalmente requeridos ou tolerados nas hagiografias - definidas como "um gênero literário que [...] privilegia os atores do sagrado (os santos) e visa à edificação (uma 'exemplaridade')" (CERTEAU, 2011, p. 289). No caso da autobiografia de Eva Mills, referem-se às ações benevolentes e educacionais que carregam consigo os ideais deste grupo religioso específico, fazendo de sua publicação um livro de edificação dos fiéis, tal qual uma hagiografia. As virtudes de um sujeito só são realmente virtudes se existir um para quem estas virtudes façam sentido. As virtudes de Eva Mills são expressões das virtudes re-

10 Do livro "O peregrino", de John Bunyan, publicado na Inglaterra em 1678. A autora compara o Calvary Fellowship Homes, asilo onde está no momento da escrita dos livros, com a Terra de Beulá, "onde crentes idosos de vários caminhos da vida vêm para se aposentar e descansar por um tempo, esperando o chamado do Rei da Cidade Celestial". (MILLS, 1976, p. 131, em tradução livre) 
queridas pelo grupo religioso do qual ela fez parte e não por acaso Eva Mills tenha sido tomada por exemplo.

Dois anos antes da publicação do 8:28, em julho de 1974, foi realizado o I Congresso Internacional sobre Evangelização Mundial, em Lausanne, Suiça. Este foi organizado pelo batista norte-americano Billy Graham, que se apresentava como uma liderança evangélica capaz de atrair o apoio e a anuência de diversos ramos do protestantismo, de diversas partes do mundo. Com o documento gerado ao fim deste evento, com o objetivo de apresentar os distintivos teológicos para a Igreja em termos de evangelização mundial,11 o Pacto de Lausanne pretendia lançar novas luzes sobre o tema da evangelização mundial e as prioridades missiológicas da igreja protestante sobre o mundo. As perspectivas missiológicas convergiam para os pobres e para o Terceiro Mundo, substanciando uma teologia voltada para as práticas sociais, em especial por meio da educação e de assistências sociais, enquanto estratégia de transformação social.

Dentre os quinze artigos elencados no Pacto de Lausanne, destacamos o intitulado "Educação e Liderança", que diz:

Confessamos que às vezes temos nos empenhado em conseguir o crescimento numérico da igreja em detrimento do espiritual, divorciando a evangelização da edificação dos crentes. Também reconhecemos que algumas de nossas missões têm sido muito remissas em treinar e incentivar líderes nacionais a assumirem suas justas responsabilidades. Contudo, apoiamos integralmente os princípios que regem a formação de uma igreja de fato nacional, e ardentemente desejamos que toda a igreja tenha líderes nacionais que manifestem um estilo cristão de liderança não em termos de domínio, mas de serviço. Reconhecemos que há uma grande necessidade de desenvolver a educação teoló-

11 O evento não absorveu caráter denominacional, havendo um interesse aglutinador e ecumênico por parte dos envolvidos. (TENNET, 2014) gica, especialmente para líderes eclesiásticos. Em toda nação e em toda cultura deve haver um eficiente programa de treinamento para pastores e leigos em doutrina, em discipulado, em evangelização, em edificação e em serviço. Este treinamento não deve depender de uma metodologia estereotipada, mas deve se desenvolver a partir de iniciativas locais criativas, de acordo com os padrões bíblicos. (THE LAUSANNE COVENANT, 1974) $)^{12}$

Este trecho do Pacto é significativo para a compreensão do que possa representar a publicação da autobiografia de Eva Mills dentro desse contexto. Havia um interesse em mudança no cenário protestante e as palavras "confessamos" e "reconhecemos" denotam o caminho que não queria mais ser trilhado, como o divórcio entre evangelização e edificação dos crentes e a não preparação de "líderes nacionais a assumirem suas justas responsabilidades", enquanto críticas a um modelo colonialista de fazer missões, no sentido tanto de propagar um modelo civilizacional, quanto de tornar os nativos dependentes em sua forma e recursos. Conceitos como "implantação" de igrejas ou mesmo da religião são questionados, inclusive no aspecto educacional, como estratégias de um modelo imperialista que visava "implantar" os modelos civilizacionais enquanto práticas voltadas para as elites de uma nação.

Contudo, as palavras de apoio que vêm em sequência apontam para aquilo que se busca agregar como identidade para as missões protestantes, ressignificando o lugar da educação enquanto prática missionária na sociedade, devendo esta ser investida prioritariamente nas "iniciativas locais" e no preparo teológico de uma liderança local - "desejamos que toda a igreja tenha líderes nacionais que manifestem um estilo cristão de liderança não

12 Disponivel em: <https://www.lausanne.org/content/ covenant/lausanne-covenant\#cov>. Acesso em: 5 abr. 2017. 
em termos de domínio, mas de serviço" (THE LAUSANNE COVENANT, 1974). Importante destacar que, no Brasil, desde o início do século, já havia um movimento de nacionalização das igrejas que se fundaram a partir de investimentos denominacionais norte-americanos, como a igreja Presbiteriana em 1903, a igreja Batista em 1907 e a igreja Metodista em 1930 (REILY, 1984).

A memória de Eva Mills e sua vida no "Norte primitivo do Brasil", como professora, está associada às representações de uma educação protestante preocupada com mudanças sociais, com a educação dos pobres e com interesse na preparação de uma liderança efetivamente nativa, instruída teologicamente para a "formação de uma igreja de fato nacional", a partir do contexto de uma região desprovida de recursos na América Latina.

Seguindo Denys Cuche, ao analisar a obra Cultura Primitiva, de Edward Burnett Tylor, o pensamento sobre a diferença cultural articulou-se inicialmente na oposição primitivo versus civilizado:

a cultura dos povos primitivos contemporâneos representava globalmente a cultura original da humanidade: ele era uma sobrevivência das primeiras fases da evolução cultural, fases pelas quais a cultura dos povos civilizados teria passado necessariamente. (CUCHE, 2002, p. 37-38)

Assim, o interesse na publicação desta autobiografia, a princípio na figura do editor Reapsome, não é fruto só dos olhos brilhantes de Eva Mills, em amizade com sua mãe, com quem compartilhava a vida no lar de idosos, mas a vida ali construída dava sentido a uma identidade de grupo, com forte apelo às práticas missionárias no Terceiro Mundo, entre povos menos favorecidos e "atrasados".

Contudo, pontuamos que as autobiografias de Eva Mills não tenham sido necessariamente escritas ou construídas deliberadamente tomando por base toda essa conjuntura socio -histórica, que envolvia tanto o meio protestante quanto sua relação com outros campos - grupos religiosos ou políticos. ${ }^{13}$ Pelo contrário, suas narrativas expõem tensões epistemológicas, revelando permanências e rupturas de um sujeito que vive e escreve a partir de um espaço entre culturas, expondo incoerências e "testemunhos involuntários" (BLOCH, 2001) entre o que a autora quer, polidamente, dizer, e aquilo que representa um olhar imperialista sobre a experiência entre os brasileiros, ao mesmo tempo que negociando com representações construídas para o seu público leitor. Enquanto Eva Mills apregoa valores como respeito e valoração do outro, por exemplo, autodescrevendo-se "tola" diante de "gigantes da floresta", também salienta uma descrição que evidencia os traços exóticos de um povo que vive em condições primitivas e selvagens, diferentes das suas.

Para além do texto bíblico anunciado, outro elemento é apresentado como justificativa para a escolha do título:

Primarily, the title was suggested by the date: 8/28/1928. It was on August 28, 1928 that I set sail from Liverpool, England, for North Brazil, in obedience to my heavenly Father's guidance. Brazil was to be the country of my joys and sorrows, where I would prove, over and over again through the years, the grand overwhelming truth of Romans, chapter eight, and verse twenty-eight. Brazil was where I learned to put in practice the lessons I had been taught in earlier years, the country to which my heavenly Father guided my steps and prepared me to go, trusting Him alone, by the fulfillment of rich promises from His Word, which liveth and

13 O "movimento Lausanne" não foi uma ação isolada do meio protestante, mas ocorre em um contexto de diálogo com a Igreja Católica, a partir do Concílio do Vaticano II, e, no contexto mais amplo, no interior das tensões políticas da Guerra Fria e do surgimento de governos ditatoriais no sul global. Na América Latina, em resposta à Teologia da Libertação, da Igreja Católica, as ideias de Lausanne ganham corpo na Teologia da Missão Integral. 
abideth for ever. It was on August 28, 1928 that I said 'Goodbye' to loved ones for Christ's sake. (MILLS, 1976, apresentação) ${ }^{14}$

Os seus 8:28's dizem, também, de uma data - o dia em que a autora começou a atravessar as águas do oceano da vida e, literalmente, da Inglaterra para o Brasil: "Foi em 28 de agosto de 1928 que eu disse 'adeus' a entes queridos pela causa de Cristo". Dois elementos, a data e o verso bíblico, conjugaram-se na construção identitária da autora. 8:28 é a representação de Eva Mills. O livro é autobiográfico, diz sobre ela, fazendo referência tanto ao marco espaço-temporal de qual vida ela procurou dar destaque - sua vida no Brasil - quanto àquilo que ela usa para dar sentido e construir sua trajetória de vida, a providência divina - "pois todas as coisas cooperam para o bem daqueles que amam a Deus".

Na capa do livro, em destaque está: "Eva Y. Mills recounts the 8:28's of her thirty years's mission in Brazil's primitive interior".5 0 vocábulo em inglês recount seria literalmente: recontar, narrar ou relatar de novo, trazer de novo à história. Atrai a atenção o prefixo "re", que traz a conotação da repetição de algo que já aconteceu outras vezes, do novamente. Eva Mills está trazendo mais uma vez à memória aquilo que já foi vivido muitas outras vezes, não só no tempo da realidade dos acontecimentos, dos fatos propriamente ditos, mas

14 [Primeiramente, o título foi sugerido pela data: 28/08/1928. Foi em 28 de agosto de 1928 que eu parti de Liverpool, Inglaterra, para o Norte do Brasil, em obediência à orientação do meu Pai celestial. O Brasil seria o país de minhas alegrias e tristezas, onde eu iria provar, por inúmeras vezes através dos anos, a esmagadora verdade de Romanos, capítulo oito, versículo vinte e oito. Foi no Brasil que eu completei na prática a lição que eu havia aprendido anos anteriores, o país para o qual meu Pai celestial guiou meus caminhos e me preparou para seguir, confiando somente nele, pelo cumprimento das ricas promessas de Sua Palavra, que vive e permanece para sempre. Foi em 28 de agosto de 1928 que eu disse "adeus" a entes queridos pela causa de Cristo. Tradução nossa.]

15 [Eva Y. Mills relembra os 8:28's de seus 30 anos de missão no interior primitivo do Brasil. Tradução nossa.] também nos tempos em que ela se narrou em cartas, em outros textos ou através da oralidade, em período anterior à publicação dos livros. $^{16}$

\section{A veracidade dos fatos}

No decorrer do "8:28", é possivel identificar uma preocupação em apresentar datas, a instituição à qual autora e o editor são afiliados, o lugar onde Eva Mills morava, a igreja em que trabalhou, muitas referências que trazem à tona o que Lejeune (2008) denominou de "pacto de referência". Para Lejeune, o "pacto de referência" é um elemento do “pacto autobiográfico", onde o autor, que é também narrador e personagem, compromete-se a dizer a sua verdade ao leitor, sobre sua própria vida, e o leitor, supostamente, a acreditar. Contudo:

é claro que, ao tentar me ver melhor, continuo me criando, passo a limpo os rascunhos de minha identidade, e esse movimento vai provisoriamente estiliza-los ou simplifica-los. Mas não brinco de me inventar. Ao seguir as vias da narrativa, ao contrário, sou fiel a minha verdade. (LEJEUNE, 2008, p. 121)

A questão em evidência não é a discussão sobre a verdade tal qual a História suscita. As histórias que Eva Mills narra se propõem reais, passiveis de verificação: ela apresentou-se, mostrou como chegou até ali, falou de seus diários, das cartas e materiais que recebeu da família na Inglaterra, capazes de trazer as lembranças e sentimentos de tempos reais:

In April 1974, Immanuel Baptist Church in Richmond, Virginia, gave me a surprise farewell

160 acesso ao arquivo pessoal de Eva Mills, disponibilizado pela família nos Estados Unidos, oportunizou perceber o caminho de amadurecimento deste processo autonarrativo por meio da escrita de correspondências e da oralidade dos testemunhos nas igrejas nos Estados Unidos pós 1945 e, assim, a forma como Eva Mills vai construindo uma identidade vinculada à docência no Brasil, em período anterior à publicação dos livros. 
before I left for Calvary Fellowship Homes in Lancaster, Pennsylvania, where I was going to spend my retirement years. During the early part of the service on that lovely Easter Sunday morning, Pastor Albert R. Fesmire called me to the microphone and gave me a few minutes to speak to my beloved 'Immanuel Family'. There, below the fragrant Easter lilies, was their parting gift. Mr. James H. Richie, Chairman of the Board of Elders, brought it to me. The gift-wrapped package, with its large gold ribbon, had not suggested a typewriter. The fact that I was no typist, that I hadn't made public any desire to engage in writing and that I was not alert enough now to consider such a venture, made the lovely gift a bigger surprise. It was a beautiful, portable, Smith Corona electric typewriter. I'm sure none of my Immanuel Family knew and neither did I - how the typewriter was to be used.

\section{[...]}

So, by the large window of my peaceful room, overlooking a beautiful Garden, at Calvary Fellowship Homes, I have penned the story of God's wise and wonderful dealings with me. Many times in my physical weakness I have sought and claimed God's promise to Paul: 'My grace is sufficient for thee: for my strength is made perfect in weakness' (2 Corinthians 12:9). Many times He has restored alertness of mind in answer to prayer. Many times, when ready to quit, I have been encouraged to continue, and helped by the patient, inspiring confidence of Editor James W. Reapsome of East Petersburg, Pa. To him I am deeply grateful. (MILLS, 1976, prefácio $)^{17}$

17 [Em abril de 1974, a Immanuel Baptist Church em Richmond, Virgínia, deu-me uma despedida surpresa, antes de partir para o Calvary Fellowship Homes, em Lancaster, Pensilvânia, onde eu iria passar os meus anos de aposentadoria. Durante a primeira parte do culto, naquela linda manhã de domingo de Páscoa, o Pastor Albert R. Fesmire chamou-me ao microfone e deu-me alguns minutos para falar à minha amada 'família Emanuel'. Ali, sob os perfumados lírios de Páscoa, estava o presente de despedida deles. O Sr. James H. Richie, Presidente do Conselho de Anciãos, trouxe-o para mim. O pacote embrulhado para presente, com sua grande fita dourada, não sugeria ser uma máquina de escrever. O fato de que eu não era datilógrafa, que eu não tinha tornado público qualquer desejo de envolver-me com a escrita e que, no
A narrativa ali expressa era a sua história e a sua verdade, a qual ela se empenhou em provar que não se tratava de um romance ficcional, mas de um livro que continha a realidade de uma vida, a sua, e o leitor poderia conferir - ela estava logo ali, no Calvary Fellowship Homes, cujo endereço constava no livro.

E se sua vida e os fatos narrados não estão para serem questionados em sua verdade, vindo, desta forma, a ser exemplo para outros, questionar as representações construídas na obra autobiográfica torna-se essencial, um meio para desvelar os valores e práticas atribuídos a partir de determinados modelos. Assim, identificar os elementos do pacto-autobiográfico ajuda a problematizar e então ampliar a perspectiva historiográfica sobre as possibilidades de análise de fontes autobiográficas, para além da biografia do próprio autor, por meio de suas representações.

Corroborando com a promessa de verdade, o livro traz ainda dois mapas: um mapa-múndi (figura 2), com marcação dos caminhos trilhados por ela entre continentes, e um recorte do mapa do Brasil (figura 3), este presente também no livro "Em Lugar do Espinheiro" (MILLS, 1982[?]), marcando a região, cidades e outros pontos que representam sua passagem por este país, pelo seu trabalho.

momento, eu não estava tão certa quanto a aventurar-me a isso, fez do belo presente uma surpresa ainda maior. Era uma bela máquina de escrever portátil Smith Corona, elétrica. Com certeza ninguém em minha família Emanuel sabia - e nem eu - o quanto aquela máquina de escrever seria usada. [...] Assim, olhando da grande janela do meu quarto tranquilo, com vista para um belo jardim, no Calvary Fellowship Homes, eu escrevi a história da sábia e maravilhosa relação de Deus comigo. Muitas vezes, em minha fraqueza física, procurei e reivindiquei a promessa de Deus a Paulo: 'Minha graça é suficiente para você: o meu poder se aperfeiçoa na fraqueza' (2 Coríntios 12: 9). Muitas vezes, Ele restaurou meu discernimento em resposta à oração. Muitas vezes, quando estava pronta a desistir, fui encorajada a continuar e ajudada pela paciente e inspiradora confiança do Editor James W. Reapsome de East Petersburg, Pensilvânia. A ele, sou profundamente grata. Tradução nossa.] 
Figura 2 - Mapa-múndi com destaque para a circulação de Eva Mills entre continentes.

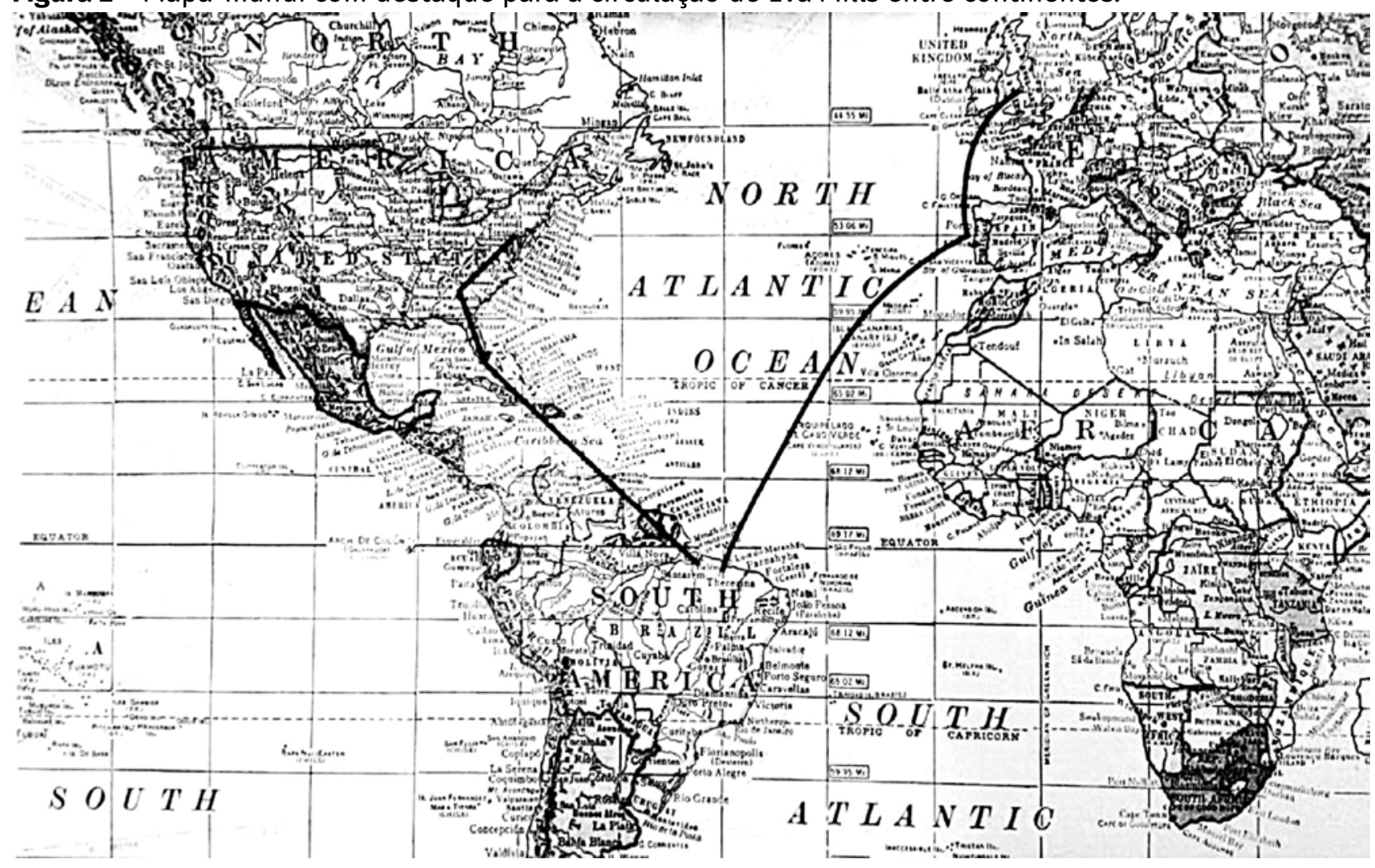

Fonte: Mills, 1976.

Figura 3 - Mapa que destaca as cidades e regiões por onde Eva Mills circulou no Brasil.

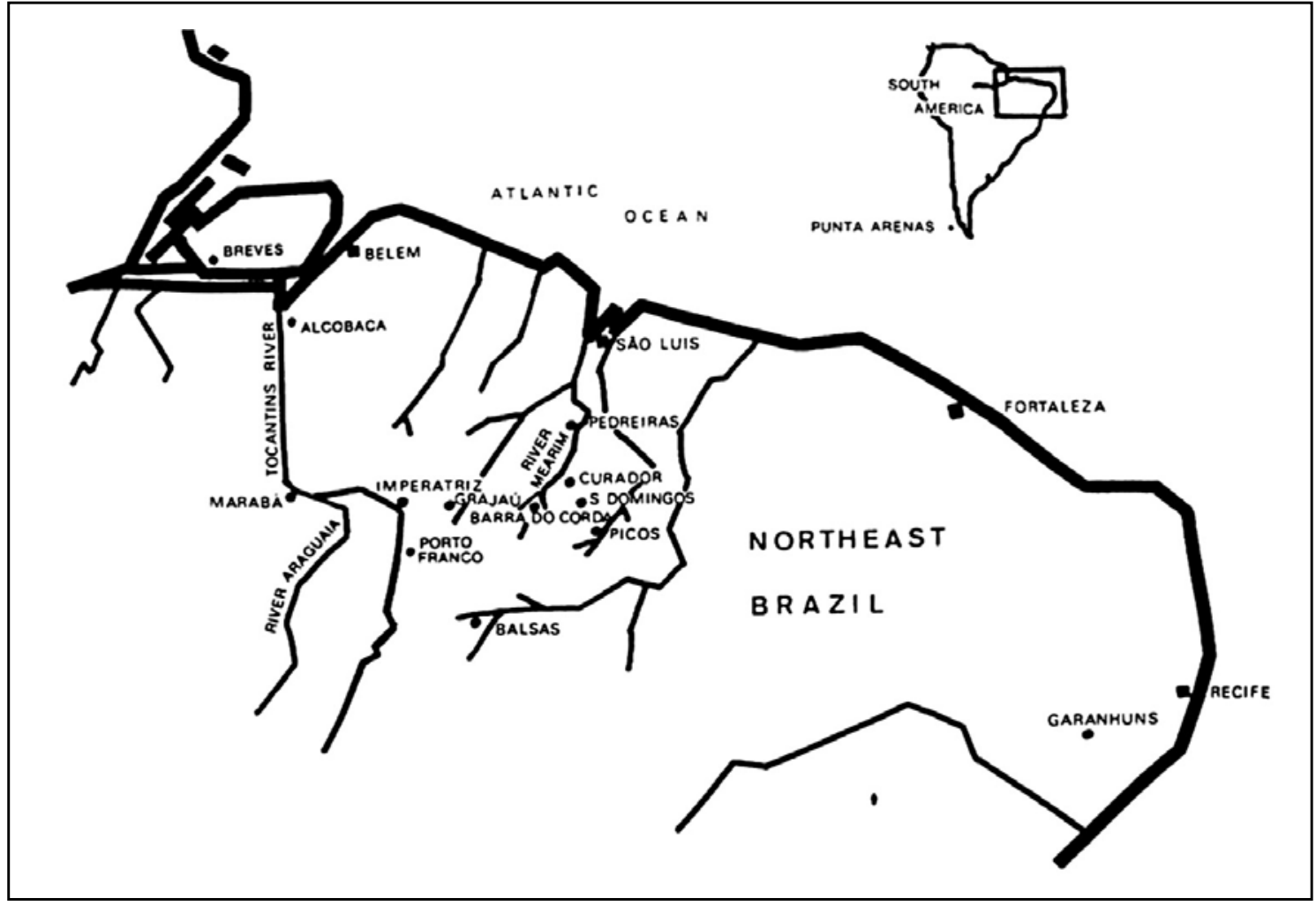

Fonte: Mills (1976; 1982[?]). 
No decorrer dos capítulos, mais imagens: desenhos assinados por Glover Shipp, um missionário norte-americano que também trabalhou no Brasil durante os anos de 1967 a 1985. São imagens do cotidiano que não só representam uma cena do capítulo onde se encontram, quanto trazem em si uma aura de verdade. Elas vão além da preocupação com a ilustração, pois, para quem tem ou teve a oportunidade de conhecer a região, a identificação é imediata, os detalhes são capazes de gerar um efeito de realidade, cumprindo o propósito pretendido.

Figura 4 - Cartão postal "Jangadas - Brasil”.

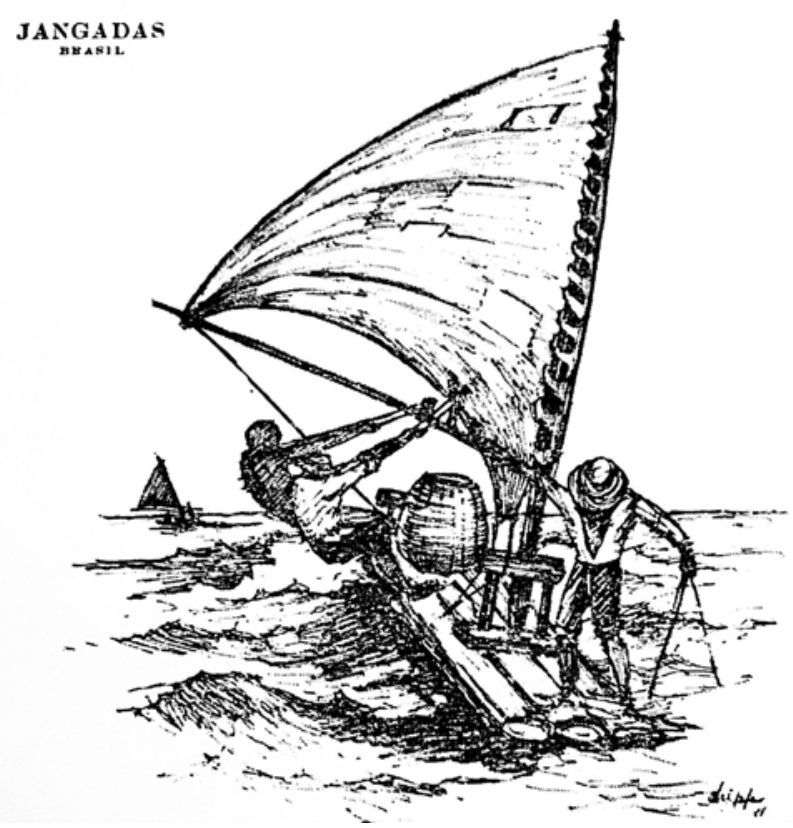

Fonte: Arquivo particular, família Doepp.

A figura 4 é a imagem de um cartão postal enviado pela filha de Eva Mills, Anna Davina, um pouco antes da publicação do livro. A correspondência expõe esta intencionalidade em aproximar o texto à ilustração. No verso do cartão, as seguintes palavras:

This is a sample of Mr. Shipp's work. Please send us few picture of scenes and people and of 'things' mentioned in the chapters. He said the could use the picture of you handing something to the Indian. What were you giving the Indian? Could the read? Mr. Shipp said once the studies the look and pictures the actual work will not take long. (DOEPP, [correspondência] 4 dez. 1975) ${ }^{18}$

Esta imagem também se encontra no livro 8:28 (1976, p. 126) e foi usada para preceder o último capítulo: "sua incansável fidelidade". Interessante perceber como a tônica deste capítulo está impressa nesta imagem, que mostra o retorno de pescadores cansados de um dia de trabalho à praia, mas com os baldes cheios do fruto de seu trabalho. Neste, a autora se despede resumindo seus últimos anos no Brasil e a cena, por sua vez, é representativa de seu próprio "retorno" que, apesar de acumular as dificuldades enfrentadas na labuta de uma vida, traz suas recompensas. Na narrativa, a descrição de uma das experiências vivenciadas quando na Casa Carmelo, uma "casa e escola"19 para filhos de missionários da Unevangelized Fields Mission - UFM na cidade de Fortaleza, CE: ${ }^{20}$

The fisherfolk lived in small shacks on the beach. Their 'jangadas', built of five roughly hewn logs fastened together and a crude mast with a single sail, left at dawn each morning. Two men pushed into the ocean their frail-looking craft with the help of two logs, over which they rolled the jangada into the water. The food for the day, a bottle of water and a bucket-like container for the fish they hoped to catch, were all tied on to the mast. There was no other protection from the waves, which swept over the floating craft at will. We watched them go. The jangadas sailed away in the morn-

18 [Esta é uma amostra do trabalho do Senhor Shipp. Por favor, nos envie algumas fotos de cenas, pessoas e de 'coisas' mencionadas nos capítulos. Ele disse que poderia usar a foto de você entregando alguma coisa ao índio. 0 que você estava dando ao índio? Consegue decifrar? O Senhor Shipp disse que depois que estudar as expressões e as imagens, o trabalho mesmo não irá demorar muito. Tradução nossa.]

19 "home and school" é o termo que Eva Mills utiliza para se referir a seus internatos e tem relação com sua concepção pedagógica acerca destas escolas. (VERAS, 2017)

20 A "Casa Carmelo" funcionou entre os anos de 1945 a 1949, como um internato para filhos de missionários da agência missionária que Eva Mills se filiou em 1940. 
ing breeze, became smaller and smaller, until, one by one, they were lost to view in their large ocean world. About sundown, the women folk - mothers, wives, daughters, sweethearts - came to scan the horizon. Somehow, each could recognize the sail that seemed to her the most familiar. As each jangada became more visible, the excitement grew. How good it was to see the fishermen again, with the day's work in their bucket. [...] Sometimes the men told of difficulties, when the wind played tricks on their sails and the jangada turned upside down. It took courage to right the craft; the fishermen worked desperately, clinging to the unsinkable logs. They often lost their fish in the upturned experience. Sometimes the wind blew the craft further out to sea and worried women watched in vain for their loved ones, who failed to return until the next day. (MILLS, 1976, p. 129) ${ }^{21}$

As imagens, que não estão ali por acaso, "assim como os textos e testemunhos orais, constituem-se numa forma importante de evi-

21 [Os pescadores moravam em pequenas cabanas na praia. As suas "jangadas", construídas com cinco troncos grosseiramente amarrados uns aos outros e um mastro rústico com uma única vela, saíam ao amanhecer todas as manhãs. Dois homens empurravam para o oceano suas embarcações aparentemente frágeis com a ajuda de dois troncos, sobre os quais rolavam a jangada até a água. A comida para o dia, uma garrafa de água e um recipiente parecido com um balde para os peixes que eles esperavam pegar estavam amarrados ao mastro. Não havia proteção contra as ondas, que varria a embarcação conforme a sua vontade. Nós os observávamos ir. As jangadas navegavam na brisa da manhã, e tornavam-se cada vez menores até que se perdiam de vista no grande mundo oceânico. Ao pôr do sol, as mulheres nativas - mães, esposas, filhas, namoradas - vinham perscrutar o horizonte. De alguma forma, cada uma conseguia reconhecer a vela que the parecia mais familiar. Â medida que cada jangada se tornava mais visivel, a emoção crescia. Como era bom ver os pescadores de novo, com o trabalho do dia em seus baldes. [...] Às vezes, os homens falavam das dificuldades, como quando o vento pregava peças em suas velas e a jangada virava de cabeça para baixo. Era preciso coragem para endireitar a embarcação; os pescadores trabalhavam desesperadamente, agarrando-se aos troncos que não afundavam. Muitas vezes eles perdiam seus peixes na experiência de desvirar a jangada. Às vezes o vento soprava a embarcação para mais longe ainda no mar e as mulheres, preocupadas, esperavam em vão os seus amados, que não conseguiam retornar até o dia seguinte. Tradução nossa.] dência histórica. Elas registram atos de testemunho ocular" (BURKE, 2005, p. 17). É como se elas trouxessem em si um "testemunho preciso", fossem uma "testemunha ocular" dos fatos tais quais são ou foram um dia. Não servem só como ilustrações do texto. Elas são o próprio texto, no sentido de trazerem, elas mesmas, uma mensagem sobre as representações dialogadas no conjunto da obra.

As imagens deste livro ilustram um país tropical e selvagem: desde os rios e árvores frondosas da região amazônica e ribeirinha, aos coqueiros e mares do litoral por onde Eva Mills passou. Esta mesma representação se perpetua nos demais livros, onde as pessoas são visibilizadas em estilo de vida primitivo e em contato com a natureza, fomentando uma representação típica de um estereótipo nortista ribeirinho ou sertanejo nordestino, ao qual a própria autora reclama sua participação (ver figuras 5 e 6).

Figura 5 - A vida missionária entre os ribeirinhos.

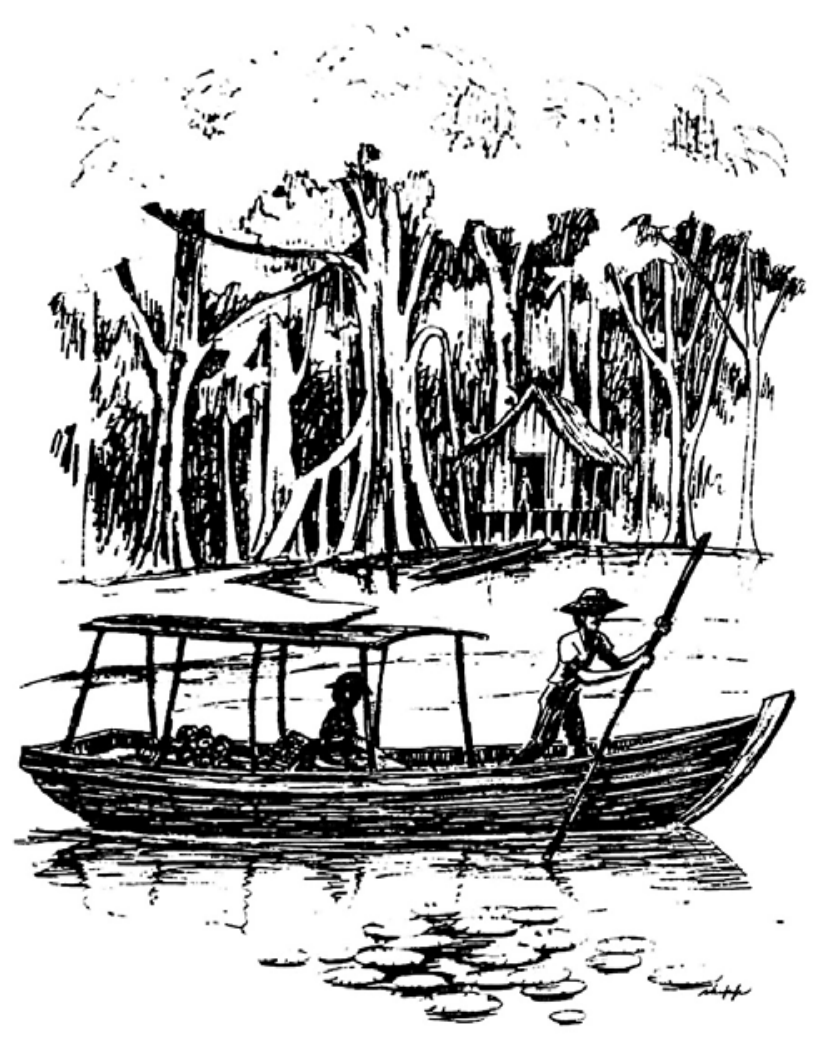

Fonte: Mills, 1976, p. 48. 
Figura 6 - A vida sertaneja.

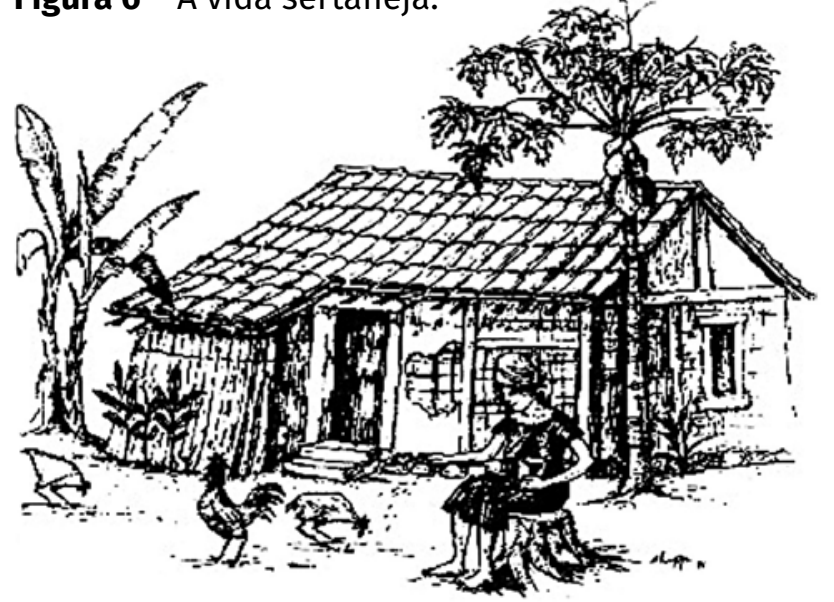

Fonte: Mills, 1976, p. 92.

Contudo, para além do ambiente ilustrado sobre a vida no campo, algumas das imagens (a exemplo das figuras anteriores) trazem à cena a figura de personagens que estão sós, algumas delas mulheres, ou a própria missionária, sob um certo ar de solidão. Estas imagens não estão descoladas da configuração total da obra e não podem ser desprezadas na análise do livro, pelas representações por elas suscitadas. De alguma forma, apesar de Eva Mills não estar presente na maioria das imagens, é sobre a autora-personagem que elas falam.

Figura 7 - "Experiências na selva"

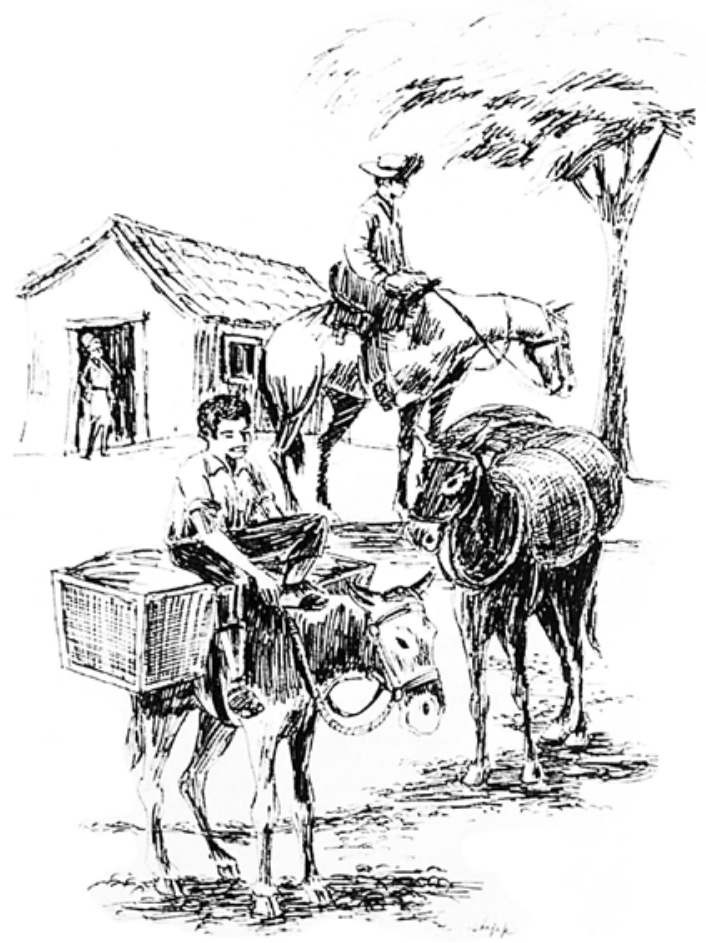

Fonte: Mills, 1976, p. 80.
Esta imagem se encontra no capítulo "Experiências na selva" - onde Eva Mills relata uma experiência entre as cidades de Imperatriz e Barra do Corda (cidades no Estado do Maranhão). Nesta história, ela e um guia perdem a trilha e ficam perdidos sob chuvas constantes, mosquitos e cobras, no meio da floresta, quando viajavam sobre o lombo de jumentos. Anastácio, o guia tão experiente que a levava, adoece de varíola, impossibilitando a continuação da viagem. Eva Mills, que antes estava sob seu cuidado, vê-se em situação oposta: “I smile to myself now as I see the city baby, who must be cared for lest any harm should come to her, now caring for the courageous giant of the jungles, grown so weak and limp" (MILLS, 1976, p. 87). ${ }^{22}$

Sob uma choupana e as promessas de cuidados de uma família que os abrigou de malgrado, por medo do contágio da enfermidade de Anastácio, ela segue viagem com um outro guia, que era quase totalmente cego. Mais à frente, encontram uma caravana enviada pelos seus: Dugal Smith (filho do missionário Perrin Smith) e um amigo, que procuram por alguma notícia de uma missionária britânica que provavelmente foi morta pelo guia, por aquela região. Era a salvação de Eva Mills e o sinal da Providência. Aqui ela retoma o verso de Romanos 8:28 e aplica lições de dependência e cuidados divinos, fala da sabedoria dos "homens da floresta" e da "sabedoria dos animais" (no retorno com Dugal Smith para casa, eles se perderam novamente, deixando que as mulas os guiassem, o que deu certo). A imagem ilustra esse encontro com os que a procuravam, mesmo achando que ela já estaria morta - o menino Dugal, seu amigo e a mula que a levaria para casa.

22 [Eu sorrio para mim mesma ao ver a menininha da cidade, que precisava ser cuidada para que nenhum mal a ferisse, agora cuidando do corajoso gigante das selvas, que ficou tão fraco e capenga. Tradução nossa.] 
Outros momentos como este são alinhavados durante a narrativa. Momentos de introspecção, reflexão, inseguranças e decisões durante sua vida no Brasil. o primeiro capítulo diz do seu despertar para a educação, o momento em que ela toma a decisão de abrir uma escola, em um momento de crise espiritual e readequação de vida. É neste capítulo que ela vai retomar sua infância e lembrar o "para que" ela fora "chamada" em sua relação com o Sagrado. No segundo capítulo, ela continua falando sobre esse "chamado", agora na juventude, seus sonhos missionários, sua relação com David Mills na construção desse sonho, ao mesmo tempo que o confronto com o pai que não aceitou sua ida/vinda para o Brasil, o que exigiu enfrentamento de sua parte para permanecer no caminho traçado. E o capítulo três, o "8:28" que deu nome ao livro, é onde ela descreve sua vinda para o Brasil, a viagem no navio, o casamento com David, que a esperava no porto de São Luís, e o primeiro contato com os brasileiros.

A sequência seguinte são relatos deste tempo no Brasil, de suas experiências com o brasileiro sertanejo, no público e no privado, nas escolas, nos momentos de culto, na relação com homens, mulheres e crianças. Eva Mills relata as mudanças, descreve o processo de adaptação às novas casas, cidades diferentes, dificuldades e uma vida experienciada na "selva", no "primitivo". Muito alinhado com o que já fora anunciado pelo editor na capa, contracapa e reforçada pelas imagens: é o longo período do martírio e do extraordinário na vida da heroína. São capítulos que guardam onze anos de intensidade, quando, após a separação do marido, ela acelera a narrativa para os quase vinte anos seguintes, no último capítulo, vai para os Estados Unidos e lá se aposenta, enferma. Descreve um pouco de sua última morada terrena, a casa de repouso onde residia, em momento de contemplação, do "olhar para trás", de colar a última peça, e finda:
I look back along the jungle trail of life and see much more clearly all the way the Lord has led me through thorny paths, difficult places and stormy challenges. His method was sublime, His thoughts supremely kind. Every turn in the path, every change in circumstances was designed by Him in loving kindness, to teach me some precious lesson, that could be learned only through such experiences. (MILLS, 1976, p. 131) ${ }^{23}$

Eva Mills publicou este livro aos setenta e três anos de idade e vem a falecer dez anos depois, publicando outros livros, escrevendo textos, cartas e memórias desta vida nos trópicos. Os outros dois livros, que possuem estilos (auto)narrativos distintos e públicos leitores diferentes, vêm a reforçar e a completar esta autobiografia e a somar com este naquilo que consideramos como a produção de um "projeto autobiográfico" (VERAS, 2017), pela construção de um "nome-próprio". ${ }^{4}$

\section{Considerações finais}

A partir da leitura do livro 8:28, pudemos ver como os sentidos construídos pela edição e autoria dialogam na materialidade do livro e

23 [eu olho para trás, para a trilha da selva da vida e vejo muito mais claramente todo o caminho que o Senhor me levou através de veredas espinhosas, lugares dificeis e desafios tempestuosos. Seu método foi sublime, Seus pensamentos extremamente amáveis. Cada mudança no caminho, cada mudança nas circunstâncias foi projetada por Ele em amor, para me ensinar algumas lições preciosas, que poderiam ser aprendidas apenas por tais experiências. Tradução nossa.]

24 Para Lejeune, "o tema profundo da autobiografia é o nome próprio" (2008, p. 40) e não necessariamente diz respeito à pessoa que narra. 0 "nome próprio" é maior do que a "simples" assinatura da obra, ultrapassa os limites da materialidade do livro e mesmo do texto ali narrado: diz do campo de recepção do livro, do público leitor - que é quem vai consentir a credibilidade necessária e legitimar a vida narrada, assegurando o "pacto autobiográfico". Segundo ele, "um autor não é uma pessoa. É uma pessoa que escreve e publica. Inscrito, a um só tempo, no texto e no extratexto, ele é a linha de contato entre eles. 0 autor se define como sendo simultaneamente uma pessoa real socialmente responsável e o produtor de um discurso. Para o leitor, que não conhece a pessoa real, embora creia em sua existência, o autor se define como a pessoa capaz de produzir aquele discurso e vai imaginá-lo, então, a partir do que ele produz". (LEJEUNE, 2008, p. 27) 
são capazes de produzir uma mensagem que extrapola o espaço do texto propriamente dito. Cada elemento na conceituação do livro torna-se um ponto de comunicação que escolhe o leitor e direciona, como propõe Chartier (2014), a um caminho de leitura.

No entanto, encontramos uma proposta de identificação entre autor-editor-leitor que, para além da preocupação com o encaminhamento das formas de leitura, suscita uma cumplicidade de pertença a um mesmo campo - o religioso protestante - e a promoção desse espaço. Essa paridade se estabelece na autoidentificação do editor, na conceituação da autora-personagem como modelo requerido e na seleção do público leitor. Essa relação se dá por meio da linguagem do livro, pelo acionamento de itens que são caros a este grupo, como a Bíblia, a identificação com o Sagrado e a valorização de elementos de um estilo de vida próprio, alinhado aos ideais da civilização (em oposição à selva) - estimado àquele momento histórico.

Percebemos o quão importante pode ser a identificação com o sagrado, no caso por meio da Bíblia, para a construção e a reconstrução de si. O texto de Romanos 8:28 foi capaz de ser como um espelho, quando a personagem ali se viu refletida. Também foi capaz de ser como uma lente de leitura, por meio da qual ela pôde rever sua vida. $E$ ainda foi como uma cola, capaz de unir as partes de uma vida e dar sentido a ela.

Nas imagens, encontramos não só a preocupação em evidenciar aspectos de veracidade exigidos em um "pacto-autobiográfico", quanto elas mesmas se consubstanciaram na construção e reafirmação de um discurso no livro, corroborando igualmente na construção identitária da autora-narradora-personagem.

Podemos inferir também a importância da autobiografia para o grupo religioso protestante, não só a partir da elaboração de sua heroína, no sentido de trazê-la enquanto modelo a ser seguido e, por isso, com direito à memorialística, mas também na construção da identidade do próprio grupo, quando define seus ideais, quando aponta os caminhos que podem servir de padrão, quando evoca o caminho do martírio e ainda conclama os "companheiros de viagem na trilha da selva da vida", o público leitor, a seguir por este caminho.

Eva Mills foi uma professora, construindose por meio da educação tanto no Brasil, quanto em suas representações nos livros. Contudo, considerar o lugar de escrita destes livros e a forma como e para quem os discursos foram proferidos, nos encaminhou a uma aproximação com seu grupo de pertença no tempo da escrita/publicação dos livros, ao que seja, o campo religioso protestante estadunidense.

Assim, considerar que os interesses religiosos possam ter determinado sua ação educacional, posto ser ela uma missionária, parece um ponto evidente na autobiografia de Eva Mills, em razão dos fins de uma educação articulada pelo protestantismo. No entanto, esta análise inicial chama a atenção para se considerarem os interesses do grupo religioso na publicação do livro e para questionar até que ponto eles foram capazes de condicionar o olhar (a escrita) da autora sobre a sua própria experiência educacional no Brasil.

\section{Referências}

BLOCH, Marc Leopold Benjamin. Apologia da história ou o oficio de historiador. Tradução de André Telles. Rio de Janeiro: Jorge Zahar Ed., 2001.

BOURDIEU, Pierre. Razões práticas: sobre a teoria da ação. Tradução de Mariza Corrêa. 10. ed. Campinas, SP: Papirus, 1996.

BURKE, Peter. Testemunha ocular: história e imagem. São Paulo: EDUSC, 2005.

CERTEAU, Michel de. Uma variante: a edificação hagiográfica. In: CERTEAU, Michel de. A escrita da His- 
tória. Tradução de Maria de Lourdes Menezes. 3. ed. Rio de Janeiro: Forense, 2011. p. 242-278.

CHARTIER, Roger. À beira da falésia: a história entre incertezas e inquietudes. Tradução de Patrícia Chittoni Ramos. Porto Alegre: Editora da UFRGS, 2002.

CHARTIER, Roger. A história cultural, entre práticas e representações; tradução de Maria Manuela GaIhardo. Rio de Janeiro: Bertrand Brasil, 1990

CHARTIER, Roger. A mão do autor e a mente do editor. Tradução de George Schlesinger. São Paulo: Editora Unesp, 2014.

CHARTIER, Roger. Cultura escrita, literatura e história. Porto Alegre: Artmed, 2001.

CUCHE, Denys. A noção de cultura nas ciências sociais. Trad. Viviane Ribeiro, 2 ed. Bauru: EDUSC, 2002

LEJEUNE, Philippe. 0 pacto autobiográfico: de Rousseau à internet. Belo Horizonte: Editora da UFMG, 2008.

MESQUIDA, Peri. Hegemonia norte-americana e educação protestante no Brasil. Juiz de Fora, MG: EDUJF; São Bernardo do Campos, SP: Editeo, 1994.

MIGNOT, Ana Chrystina Venâncio. Baú de memórias, bastidores de histórias: o legado pioneiro de Armanda Álvaro Alberto. Bragança Paulista, SP: Editora da Universidade de São Francisco, 2002.

MIGNOT, Ana Cristina Venâncio; CUNHA, Maria Teresa Santos. (Orgs.). Práticas de memória docente. São Paulo: Cortez, 2003.

MILLS, Eva. 8:28. Lancaster: Brookshire Publications, 1976.

MILLS, Eva. Em lugar do espinheiro. Belém: Missão Cristã Evangélica do Brasil, 1982[?].

MILLS, Eva. Stories from parakeet country. Lancaster: Ufm internacional, 1985[?].

NASCIMENTO, Ester F. V. C. Educar, curar, salvar: uma ilha de civilização no Brasil tropical. Maceió: EDUFAL, 2007.

POLLAK, Michael. Memória e identidade social. Estudos Históricos, Rio de Janeiro, v. 5, n. 10, p. 2002012, 1992.
RAMALHO, Jether Pereira. Prática educativa e sociedade: um estudo de sociologia da educação. Rio de Janeiro: Zahar Editores, 1976.

REAPSOME, Janes. The imitation of Saint Paul: examining our lives in light of his example. Eugene, Oregon: Cascade Books, 2013.

REILY, Ducan Alexander. História documental do protestantismo no Brasil. São Paulo: Aste, 1984

SILVA, Alexandra Lima da. Narrativas de vida de ex-escravos como fonte/objeto para a história da educação. In: VASCONCELOS, M. C. C.; CORDEIRO, V. M. R.; VICENTE, P. P. (Orgs.). (Auto)biografia, literatura e história. Curitiba: CVR, 2014. p. 129-145.

SOUZA, Elizeu Clementino de.; PASSEGGI, Maria da Conceição. Apresentação. Dossiê (Auto)biografia e educação: pesquisa e práticas de formação. Educação em Revista, Belo Horizonte, v. 27, n. 1, p. 327-332, 2011.

TENNENT, Timothy C. The Lausanne Movement: a range of perspectives. Oxford: Regnum Books, 2014. Disponivel em: <https://www.lausanne.org/pt-br/ recursos-multimidia-pt-br/o-movimento-de-lausana-e-o-evangelicalismo-global-distintivos-teologicos-e-impacto- missiologico>. Acesso em: 5 abr. 2017.

THE LAUSANNE COVENANT, 1974. Disponivel em: <https://www.lausanne.org/content/covenant/lausanne-covenant\#cov >. Acesso em: 5 abr. 2017.

VERAS, Loyde Anne Carreiro Silva. Memórias da Terra de Beulá: a construção de uma vida e a produção de um lugar nas autobiografias de Eva Mills. 2017. 193 f. Dissertação (Mestrado em Educação) - Escola de Educação e Humanidades, Pontifícia Universidade Católica do Paraná - PUCPR, Curitiba, 2017.

VIEIRA, César R.; NASCIMENTO, Ester F. V. C. (Orgs.). Contribuições do protestantismo para a história da educação no Brasil e em Portugal. Piracicaba, SP: Editora da Unimep, 2016.

WEBER, Max. A ética protestante e o "espírito" do capitalismo. Tradução de José Marcos M. Macedo. São Paulo: Companhia das Letras, 2004.

Recebido em: 31.05.2018 Aprovado em: 22.01.2019 
Loyde Anne Carreiro Silva Veras é Doutoranda em Educação pela Pontifícia Universidade Católica do Paraná. Mestre em Educação pela Pontifícia Universidade Católica do Paraná. Grupo de Pesquisa: Pensamento Educacional Brasileiro: Histórias e Políticas. e-mail: loydeanne08@gmail.com

Rua São José 500, Bl 3, ap. 91, Cristo Rei, Curitiba/PR Tel.: (41) 99609.3033

Evelyn de Almeida Orlando é Professora da Escola de Educação e Humanidades e do Programa de Pós-Graduação em Educação da Pontifícia Universidade Católica do Paraná. Doutora em Educação pela Universidade Estadual do Rio de Janeiro. Vice-líder do Grupo de Pesquisa Pensamento Educacional Brasileiro: Histórias e Políticas. e-mail: evelynorlando@gmail.com

Rua Nicolau Maeder 184, ap. 106, Alto da Glória, Curitiba/PR Tel.: (41) 99188.5544 